Covered in: Web of Sciences (WOS); EBSCO; ERIH+; Google Scholar; Index Copernicus; Ideas RePeC; Econpapers; Socionet; CEEOL; Ulrich ProQuest; Cabell, Journalseek; Scipio; Philpapers; SHERPA/RoMEO repositories; KVK; WorldCat; CrossRef; CrossCheck

2018, Volume 10, Issue 1, pages: 123-135 | doi: https://doi.org/10.18662/rrem/23

\section{Comparative Study on Approaching Inclusive Physical Education from the Perspective of Alternative Pedagogies}

\author{
Alina-Gabriela \\ RUSĂNESCU ${ }^{1}$, \\ Ana-Maria SORA ${ }^{2}$, \\ Marius STOICESCU ${ }^{3} *$
}

\author{
${ }^{1}$ National University of Physical \\ Education and Sports, Bucharest, \\ Romania, \\ alina rusanescu@yahoo.com \\ ${ }^{2}$ National University of Physical \\ Education and Sports, Bucharest, \\ Romania,
} moraru.alexa.ana.maria@gmail.com ${ }^{3}$ National University of Physical Education and Sports, Bucharest, Romania, mariusstoicescu@yahoo.com Corresponding author

\begin{abstract}
This century is characterized by rapid changes in society. In this light, education must help children by guiding the school to new forms of learning that give the students the opportunity to respond to unforeseen situations. Various ways to promote inclusive education are being explored nowadays, as an alternative for children with special educational needs (SEN). In this context, inclusive physical education is a methodological orientation aimed at organizing the learning process with mixed teams, which include pupils with and without deficiencies. A childcentered pedagogy is being promoted in this way, intended to reduce segregation and provide educational solutions regardless of the children's level of abilities. Alternative pedagogies are one of the resources of conceptual and methodological development of inclusive physical education. These are present perspectives of approaching education by providing the teacher with variants of organizing the teaching-learning-assessment activity in accordance with the needs of students with SEN. This paper aims to highlight the specific way in which alternative pedagogies provide educational resources for the successful implementation of inclusive physical education programs. In this respect, a comparative analysis of educational alternatives is presented according to the organizational, curricular and didactic criteria that apply to the teaching process of physical education to classes in which children with SENs are integrated. At the same time, methodological suggestions are offered on optimizing the teaching of inclusive physical education.
\end{abstract}

Keywords: Alternative pedagogies, inclusive physical education, special education, children with special educational needs, child centered pedagogy.

How to cite: Rusanescu, A.-G., Sora, A.-M., \& Stoicescu, M. (2018). Comparative Study on Approaching Inclusive Physical Education from the Perspective of Alternative Pedagogies. Revista Romaneasca pentru Educatie Multidimensionala, 10(1), 123-135. https://doi.org/10.18662/rrem/23 


\section{Introduction}

In modern education systems there is a permanent concern to provide effective training programs that are consistent with individual educational needs. Physical education and sport, as curriculum subject, falls within the current methodological orientations through a constant search for tools and means specific to quality education.

Having a strong negative impact at individual level, exclusion can be expressed in two forms: complete exclusion and functional exclusion. Full exclusion is about segregation of a student by peers, while functional exclusion involves assigning tasks during the lesson without active participation during the training.

In contrast, inclusion is both a set of actions, especially attitudes, appreciation, trust, acceptance at the individual and system level. Inclusion also means designing learning opportunities or creating training communities where all students have the opportunity to develop themselves in accordance with their own intellectual and physical characteristics.

A global phenomenon, inclusive education supports the idea that students with special educational needs should be able to participate in the educational process in regular classrooms. National education policies play an important role in shaping the teachers' attitude towards inclusive education.

Moreover, the way in which inclusion is organized, implemented and evaluated in education is reflected in the curriculum characteristics, the scoring system, the organization of the teaching and the types of evaluation, the finalities pursued, and in the diversity of the school population.

Inclusion, in essence, is not about satisfying the needs of a minority group of society; it is rather a right of every individual, with or without disabilities, to participate in their own education and development as a person. In addition, it is how people with special educational needs demonstrate to the world that they are part of the society. And this idea must continue to be developed.

The benefits of physical activity are universal for all children, including those with disabilities. The participation of children with disabilities in sports and leisure activities promotes inclusion, minimizes deconditioning, improves physical functioning, and increases overall welfare(Murphy \& Carbone, 2008 ). 


\section{Theoretical background}

Given the attitude of the school environment towards students with special educational needs, the issue of inclusive physical education is topical for the physical education and sport experts.

According to Nicoletti and García (2015), physical education is part of the human right to education, but adaptations of educational and sporting practices must be made, so that all students can actively participate in lessons, regardless of their level of deficiency (Nicoletti \& Garcia, 2015).

Alternative pedagogies are one of the resources of conceptual and methodological development of inclusive physical education. These are present perspectives of approaching education by providing the teacher with variants of organizing the teaching-learning-assessment activity in accordance with the needs of students with SEN.

Although inclusive physical education is often seen as a parallel approach, in recent years many curricular initiatives with applicability in inclusive education have emerged, such as interdisciplinary curriculum (Kaittani, Kouli, Derri, \& Kioumourtzoglou, 2017), use of information and communication technology (Adyrkhaev 2016), cooperative learning (Callado, Aranda, \& Pastor, 2014 ), (Andre, Deneuve, \& Louvet, 2011), (Klavina, Jerlinder, Kristen, Hammar, \& Soulie, 2014), multicultural education (Jepkorir, You, \& Russell, 2000), constructivist learning (Munafo, 2014), or teaching for student responsibility (Gordon, 2012).

\section{Aim of the paper}

This paper aims to highlight the specific way in which alternative pedagogies provide educational resources for the successful implementation of inclusive physical education programs.

\section{Inclusive physical education}

Inclusive physical education is a methodological orientation aimed at organizing the learning process with mixed teams, which include pupils with and without deficiencies. In this sense, a child-centered pedagogy is being promoted in this way, intended to reduce segregation and provide educational solutions regardless of the children's level of abilities.

In their attempt to create an environment conducive to inclusive physical education, teachers should take into account a series of individual characteristics of the students: physical and mental capacity, socio-economic 
status, cultural, social and environmental factors, motivation and personal goals (Trip, Rizzo, \& Webbert, 2007).

By analyzing inclusive physical education as a new orientation in the theory and methodology of physical education, confronted with the need to carry out activities in groups bringing together children with and without deficiencies, some characterization paths have been identified, such as: the social perception of people with disabilities, the adaptation of physical education to the particularities of the new student collectives, the theoretical foundations for an inclusive curriculum, the training of specialists for inclusive physical education.

To achieve inclusive physical education, the level of training of specialists (teachers, coaches) is very important - specialized knowledge, didactic skills and understanding of pedagogy aspects that ensure the link between inclusive education and physical education (Stanescu, 2008).

It takes willingness and ability to improve, in order to help students with deficiencies benefit from the new training strategies, as well as tight collaboration between the physical education teacher and the support teacher.

Access to physical education activities is crucial for students with SEN. Their participation in unified sports competitions has generated positive friendship friendships between students based on acceptance, adhesion, mutual help or dedication. Therefore, alongside the methodological guidelines and existing curriculum models, it is the attitude of the teaching staff and all those involved in the educational process that can favor the inclusion of students with SEN (Bota, Teodorescu, \& Serbanoiu, 2017).

Considering the above, the benefits of inclusion for students with special educational requirements can be classified as follows: improving motor skills and fitness, developing communication skills and feeling of belonging, increasing self-confidence, and regarding the group, improving social relationships, establishing friendship relationships, gathering knowledge about the rules of games.

As well as identifying the benefits for students with special educational requirements, positive attitudes are seen at other partners within the inclusive physical education lessons, such as: improving fitness, understanding the differences in terms of physical capacity, improving the communication strategies, developing friendship relationships, respecting individual identities, promoting inclusion within the school community. 


\subsection{Inclusive physical education - international approach}

According to the World Declaration on Education for All, the learning needs of the disabled demand special attention. Steps need to be taken to provide equal access to education to every category of disabled person as an integral part of the education system (Abellan, H., \& Frutos, 2014). In the European Union, there is a tendency to promote the inclusion of children with SEN in ordinary schools by offering teachers various forms of assistance, such as: training courses, equipment, additional specialized staff, teaching materials (Schumaker et al., 2002)

At international level, inclusive physical education has different approaches: in Spain, teacher training courses have been developed, with the view that the success of implementing inclusion in physical education lies at the basis of the concrete knowledge of this new concept (Abellan et al., 2014). In the Netherlands the Dutch curriculum places inclusive physical education before the mother tongue, mathematics and life sciences. Physical education is used in Hungary as a basic means for the education of children with disabilities, and in Italy the principles of inclusion of people with SEN are carried out from birth to university.

\subsection{Inclusive physical education in Romania}

Currently, in Romania there are no inclusive schools in the true sense of the word, just ordinary schools that have become integrative schools for students with SEN. Also, the educational support services are underdeveloped, and the inclusion of students in ordinary schools is cumbersome because of the mentality of society.

In spite of these, during the last few years, various organizations and non-governmental bodies have started projects that aimed to create inclusive schools in Romania. Their success at the national level was not remarkable due to the segregated view of the Romanian society regarding the persons with special educational requirements.

Although the literature provides information on adapted physical education, the issue of inclusive education has been poorly addressed. Inclusive Physical Education is a new field, on which both theory and didactics can make important contributions in order to establish a unitary learning methodology that is beneficial to the development of children with disabilities. 


\section{Alternative pedagogies}

In the international literature, there are numerous books, textbooks, studies and articles dealing with alternative programs.

Internationally, these alternative programs are much better addressed, being encountered at different levels of education. These pedagogy methods have spread in many countries, such as the United States of America, the Netherlands, Switzerland, Britain, France, Germany and beyond.

Within the education system in Romania, through the initiatives carried out at central, regional and local level, many educational alternatives applicable in education have been introduced after 1990, including Waldorf, Montessori, Curative Pedagogy and Step by Step.

The common features of alternative pedagogies:

- Flexibility

- They are open to communication and collaboration with all educational partners

- Promotes the development of children's maximum potential

- Supports individualization in education

- Stimulates healthy social relationships among all members of the educational community.

In terms of the learning process, alternative schools have succeeded - up to a certain level - to be a role model for mass education. This is supported by the high number of teaching strategies and evaluation methods developed within the alternative pedagogies that have been applied in public schools worldwide (Sliwka, 2008).

Many parents believe that alternative pedagogies target only children with special requirements, or that they are a form of private education, or that teaching is done exclusively in foreign languages. In fact, an educational alternative proposes forms and methods of organization and functioning of the educational-training process, different from the traditional ones, for the achievement of the educational objectives, either in a state or private institution (Catana, 2015).

In order to integrate pupils with special educational requirements, the use of alternative pedagogies is an effective solution through the educational environment favorable to them (Danner \& Fowler, 2015).

\section{Waldorf}

The basic principle of this pedagogy is the recognition that each person is unique and goes through different periods of life. Its role is to 
respond to all the needs specific to each development phase for a harmonious development of personality.

The key word of the Waldorf pedagogy is Freedom. Freedom implies every human being's right to become mature and develop in the direction he / she desires. In this alternative, man is a human being with body, soul and spirit, and is constantly developing, while the child is considered to be a human being whose consciousness goes through different stages of development until it reaches maturity (Damovska, 2005).

Waldorf School physical education classes encourage teamwork rather than competition. Until the third grade, the focus is on motion games, and starting with the 4th grade various sports games are gradually introduced.

Robinson (2008) was totally dissatisfied with the current level of Waldorf education research (Robinson, 2008). This alternative has been criticized in relation with the methodology and curriculum, and postponing the development of writing and reading skills is not accepted by all parents.

There are currently 231 school units using the Waldorf method of teaching, 181 classes of 4110 students, spread across several counties: Bucharest, Cluj, Timisoara, Mures, etc.

\section{Montessori}

There are 82 school units that use Montessori teaching, 56 classes of 780 pupils, spread across several counties: Bucharest, Cluj, Ilfov, Sibiu, etc.

The Montessori alternative is centered on the idea of freedom for children. If a child is free, then he/she depends less on adults. The educator observes the child and prepares the environment, creating learning situations. The adult is a guide that helps the child turn to the materials he/she needs at that age, and has the capacity to discover the child's qualities.

Answers from a research on teacher perceptions about the way in which Montessori education influences the children's ability to learn and develop, highlight differences between the family objectives and the teacher goals (Epstein, 2015).

The curriculum is highly individualized, but it has very clear goals and areas. This individualization helps small children master reading and writing skills before the age of 6 , through the Montessori methods. From the age of 12 to 18, they learn to develop themselves as social beings, to provide solutions to the problems of the real world and to think rationally (Edwards, 2002). 


\section{Step by Step}

The Soros Foundation for an Open Society, in 1994, first introduced a new educational concept, dedicated to pre-school children from families with a disadvantaged socio-economic background. In addition to educationrelated services, this program also provided health care services and encouraged parents to be involved in all program activities (Deming, 2009). Initially called "Head Start," it was made known in 15 countries in Central and Eastern Europe.

This alternative focuses on the idea that the child is unique, growing and developing him/herself on a specific pace, and that leads to knowledge and respect of his or her level of development.

The basis of this pedagogy is to promote democratic principles that encourage children to become active citizens and appreciate a democratic life, formulate and express their own opinions and ask questions, and intervene in various discussions. It also promotes student-centered education, teaching is geared to the needs and interests of the students, learning is organized in centers of activity, and family and community are involved in the children's education while respecting the national and national curriculum (Balas, 2016).

There are currently 904 school units using the Step by Step teaching method, 1140 classes of 28428 students, spread across several counties: Dâmbovita, Bucharest, Bihor, Maramures, etc.

The Step by Step program focuses on child-centered education and the teaching activities are geared to the child's needs and interests; learning is organized in centers of activity, and groups.

The program focuses more on developing the "child as a whole" than on academic training through training methods, although in recent years it has been proposed to pursue a more academic program (Haskins, 2004).

\section{Curative pedagogy}

Anthroposophical curative pedagogy comes from the philosophical and pedagogical ideas of Rudolf Steiner. Curative pedagogy actually refers to the education and learning of people with special needs.

In curative pedagogy there is a foundation in education as well as in medical and social practice. The first patients of this alternative were a few children with special needs, with various forms of intellectual and behavioral problems (Edlund, 2005).

In this system there is a multidisciplinary approach; the professional approach is made in relation to the physical, emotional and spiritual aspects 
of children and adults with special needs. This includes care, education, artistic activities as well as medical and therapeutic elements (Hart \& Monteux, 2004).

At present there are 53 schools that use the Curative pedagogy teaching method, 60 classes of 338 pupils, spread across several counties, such as Hunedoara, Bucharest, Harghita, Mures, Brasov and Cluj-Napoca.

\section{Discussions}

Traditional approach represents a practical sequence that includes the explanation of a skill followed by multiple attempts in isolated conditions according to a template concluded with a bilateral game. A childcentered approach offers solutions to deliver specific content in accordance with the needs of children's affective and cognitive development.

We present in table 1 the differences and similarities between traditional, inclusive and alternative education. This approach can be a starting point for the physical education teacher in order to implement different characteristics of the alternative pedagogies into the inclusive physical education class.

Table 1. Differences between traditional, inclusive and alternative education

\begin{tabular}{|c|c|c|c|c|c|c|}
\hline & Traditional & Waldorf & Montessori & Step by Step & $\begin{array}{l}\text { Curative } \\
\text { pedagogy }\end{array}$ & $\begin{array}{l}\text { Inclusive } \\
\text { education }\end{array}$ \\
\hline $\begin{array}{l}\text { System } \\
\text { intervention }\end{array}$ & $\begin{array}{l}\text { Goals and } \\
\text { skills oriented }\end{array}$ & $\begin{array}{l}\text { Child- } \\
\text { centered }\end{array}$ & $\begin{array}{l}\text { Child- } \\
\text { centered }\end{array}$ & $\begin{array}{l}\text { Child- } \\
\text { centered }\end{array}$ & $\begin{array}{l}\text { Child- } \\
\text { centered }\end{array}$ & $\begin{array}{l}\text { Child- } \\
\text { centered }\end{array}$ \\
\hline $\begin{array}{l}\text { Curriculum } \\
\text { Organization }\end{array}$ & $\begin{array}{l}\text { National } \\
\text { frontal } \\
\text { individual } \\
\text { group } \\
\text { on pairs }\end{array}$ & $\begin{array}{l}\text { Specific } \\
\text { individual } \\
\text { group }\end{array}$ & $\begin{array}{l}\text { Specific } \\
\text { individual } \\
\text { group }\end{array}$ & $\begin{array}{l}\text { National } \\
\text { individual } \\
\text { group }\end{array}$ & $\begin{array}{l}\text { Adapted } \\
\text { individual } \\
\text { group }\end{array}$ & $\begin{array}{l}\text { Adapted } \\
\text { individual } \\
\text { group }\end{array}$ \\
\hline Teaching & frontal & $\begin{array}{l}\text { frontal } \\
\text { in epoch }\end{array}$ & $\begin{array}{l}\text { individualized \& } \\
\text { differentiated }\end{array}$ & $\begin{array}{l}\text { activity } \\
\text { centered }\end{array}$ & $\begin{array}{l}\text { frontal } \\
\text { in epoch }\end{array}$ & individualized \\
\hline Evaluation & $\begin{array}{l}\text { initial } \\
\text { formative } \\
\text { summative }\end{array}$ & $\begin{array}{l}\text { continuous } \\
\text { process }\end{array}$ & $\begin{array}{l}\text { continuous } \\
\text { process }\end{array}$ & $\begin{array}{l}\text { continuous } \\
\text { process }\end{array}$ & $\begin{array}{l}\text { continuous } \\
\text { process }\end{array}$ & $\begin{array}{l}\text { continuous } \\
\text { process } \\
\text { (formative) }\end{array}$ \\
\hline Grading & catalogue: & characteriza & portfolio & evaluation & characteriza & catalogue: \\
\hline system & $\begin{array}{l}\text { - qualifiers } \\
\text { - grades }\end{array}$ & tion sheets & $\begin{array}{l}\text { through } \\
\text { progress sheets }\end{array}$ & papers & tion sheets & $\begin{array}{l}\text { - qualifiers } \\
\text { - grades }\end{array}$ \\
\hline Teacher & $\begin{array}{l}\text { the focus } \\
\text { on the }\end{array}$ & $\begin{array}{l}\text { takes } \\
\text { initiatives, }\end{array}$ & $\begin{array}{l}\text { it's having a } \\
\text { very }\end{array}$ & $\begin{array}{l}\text { supervise and } \\
\text { provides }\end{array}$ & $\begin{array}{l}\text { takes } \\
\text { initiatives, }\end{array}$ & $\begin{array}{l}\text { creates } \\
\text { learning }\end{array}$ \\
\hline
\end{tabular}


Comparative Study on Approaching Inclusive Physical Education from the ... Alina-Gabriela RUSĂNESCU, Ana-Maria SORA, Marius STOICESCU

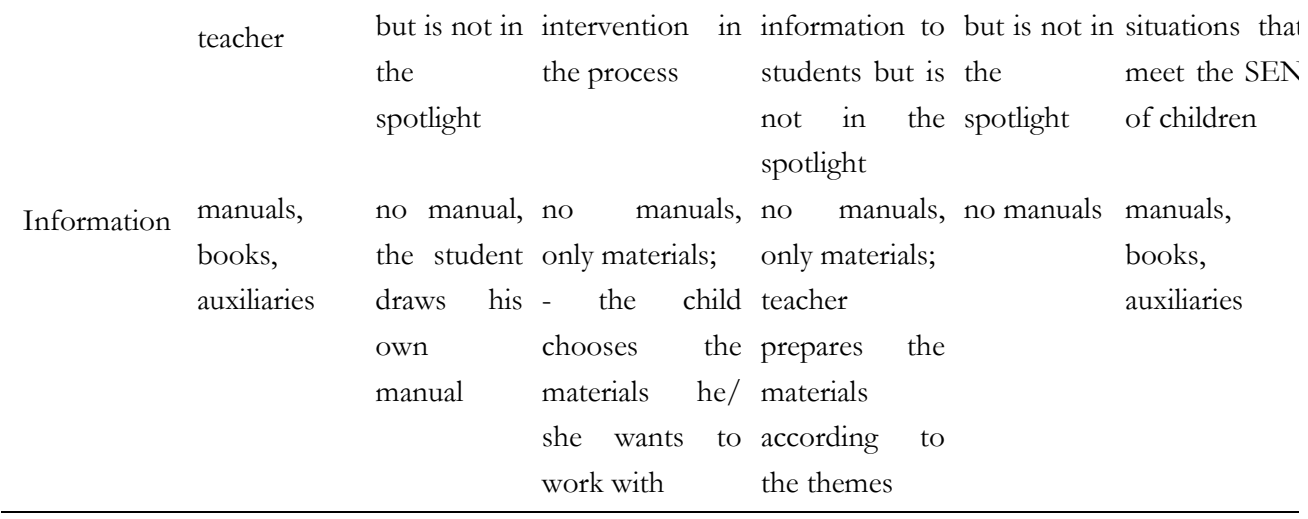

In Romania, in 2015-2018, all alternative pedagogies saw a continuous increase both in the number of classes and in the number of students (table 2). The exception, however, is the Montessori pedagogy. In the school year 2015-2016 there were 64 classes, in 2016-2017 the number of classes dropped to 45, and in 2017-2018 it rose again to a number of 56 classes. It is worth mentioning that, although in 2016-2017 the number of classes decreased, the number of pupils was continuously increasing in the school years 2015-2016 (521 students), 2016-2017 (662 students), and 20172018 (780 pupils).

Table 2. The number of classes and students (2015-2018)

\begin{tabular}{ccccccccc}
\hline $\begin{array}{c}\text { Alternative } \\
\text { Pedagogies }\end{array}$ & \multicolumn{2}{c}{ Waldorf } & \multicolumn{2}{c}{ Montessori } & \multicolumn{2}{c}{ Step by Step } & \multicolumn{2}{c}{ Curative pedagogy } \\
\hline Year & Classes & Students & Classes & Students & Classes & Students & Classes & Students \\
$2015-2016$ & 149 & 3337 & 64 & 521 & 1057 & 25920 & 47 & 265 \\
$2016-2017$ & 158 & 3610 & 45 & 662 & 1072 & 26458 & 56 & 331 \\
$2017-2018$ & 181 & 4110 & 56 & 780 & 1140 & 28428 & 60 & 338 \\
\hline
\end{tabular}

\section{Conclusions}

Each child has an innate educational potential, which must only be discovered, activated and materialized

The use of such alternative pedagogies in Inclusive Physical Education implies the use of teaching-learning methods, focused on the subject's action, which corresponds to the special educational needs of the children. In this way, the children will be more active involved and conscious.

Our comparative analysis of educational alternatives for classes in which children with SENs are integrated provide the general view of the 
educational resources for the successful implementation of inclusive physical education programs.

The differences and the similarities between the educational alternatives presented according to the organizational, curricular and didactic criteria that apply to the teaching process represents new methodological framework approach for optimizing the teaching of inclusive physical education.

The increasing number of classes and students that follow alternative pedagogies makes us rethinking the physical education and to search continuously new methods to build up a more attractive and efficient lesson.

\section{Acknowledgement}

This paper is made and published under the aegis of the National University of Physical Education and Sports as part of doctoral studies.

\section{References}

Abellan, R. M., H., R. R., \& Frutos, A. E. (2014). Una aproximacion a la educacion inclusiva en Espana. Revista de Educacion Inclusiva, 3, 149164.

Adyrkhaev, S. G. (2016). Modern technology of physical education of disabled students in conditions of inclusive education. Pedagogics, psychology, medical-biological problems of physical training and sports, 20.

Andre, A., Deneuve, P., \& Louvet, B. (2011). Cooperative Learning in Physical Education and Acceptance of Students with Learning Disabilities. Journal of Applied Sport Psychology, 23(4).

Balas, E. (2016). Educational Alternatives in the Romanian Education System Journal Plus Education, 16, 304 - 316.

Bota, A., Teodorescu, S., \& Serbanoiu, S. (2017). Unified Sports - a Social Inclusion Factor in School Communities for Young People with Intellectual Disabilities. Procedia - Social and Behavioral Sciences, 117(21).

Callado, C. V., Aranda, A., . F. , \& Pastor, V. M. L. (2014 ). Cooperative Learning in Physical Education (Vol. 20).

Catana, L. (2015). Educational alternatives in the pre-university education, from the parents perspective. Global Journal for Research Analysis, 4(6), 394-396.

Damovska, L. (2005). The Waldorf pedagogy and children with special education needs. Journal of Special Education and Rebabilitation, 6(2). 
Danner, N., \& Fowler, S. A. (2015). Montessori and Non-Montessori Early Childhood Teachers' Attitudes toward Inclusion and Access. Journal of Montessori, 1(1), 28-41.

Deming, D. (2009). Early Childhood Intervention and Life-Cycle Skill Development: Evidence from Head Start, American Economic Applied Economics, 1(3), 111-134.

Edlund, B. (2005). Anthroposophical Curative Education in the Third Reich: The Advantages of an Outsider. Scandinavian Journal of Disability Research, 7(3-4), 176-193.

Edwards, C. P. (2002). Three approaches from Europe: Waldorf, Montessori, and Reggio Emilia. Early Childhood Research and Practice, 4(1).

Epstein, A. (2015). Montessori Early Childhood Teacher Perceptions of Family Priorities and Stressors. Journal of Montessori Research, 1(1), 1-13

Gordon, B. (2012). Teaching personal and social responsibility through secondary school physical education: the New Zealand experience. (Vol. 1): 14.

Hart, N., \& Monteux, A. (2004). An Introduction to Camphill Communities and the BA in Curative Education. Scottish Journal of Residential Child Care, 3(1).

Haskins, R. (2004). Competing Visions. Education Next, 4(1), 26-33.

Jepkorir, R. R. T., You, J., \& Russell, J. (2000). In-service physical education teachers: Background and understanding of multicultural education. Journal of In-service Education, 26(3), 557-568.

Kaittani, D., Kouli, O., Derri, V., \& Kioumourtzoglou, E. (2017). Interdisciplinary teaching in physical education. Arab Journal of Nutrition and Exercise, 2(91-101).

Klavina, A., Jerlinder, K., Kristen, L., Hammar, L., \& Soulie, T. (2014). Cooperative oriented learning in inclusive physical education. European Journal of Special Needs Education, 29(2), 119-134.

Munafo, C. (2014). The Role of the Social Constructivism in Physical Education. International Journal of Science Culture and Sport, 4(4), 489497.

Murphy, N. A., \& Carbone, P. S. (2008). Promoting the participation of children with disabilities in sports, recreation, and physical activities.Council on Children with Disabilities. Pediatrics., 121(5).

Nicoletti, J. A., \& Garcia, G. (2015). El derecho humano a la educacion fisica adaptada. . Revista Digital de Educacion Fisica, 35, 70-75.

Robinson, I. (2008). The Delusional World of Rudolf Steiner. Journal of the Rationalist Society, 78(2). 
Schumaker, J. B., Deshler, D. D., Bulgren, J. A., Davis, B., Lenz, B. K., \& Grossen, B. (2002). Access of adolescents with disabilities to general education curriculum: Myth or reality? . Focus on Exceptional Children, $35(3)$.

Sliwka, A. (2008). Innovating to learn, learning to innovate. The contribution of alternative education. Paris: OECD Publishing.

Stanescu, M. (2008). Modele de proiectare curriculara pentru educatia fizica adaptata si incluriva. Bucuresti: Editura Didactica si Pedagogica.

Trip, A., Rizzo, T. L., \& Webbert, L. (2007). Inclusion in Physical Education: Changing the Culture Journal of Physical Education, Recreation \& Dance, 78(2), 32-36. 